\title{
The Impact of Moringa Leaves, Katuk Leaves and Oxytocin Massage on Quantity and Quality of Mother's Milk as Patients Health Center in Bali
}

\author{
Ni Putu Mastiningsih * \\ Midwifery, Health Institute of Bina Usada Bali, Tegal Luwih Road, Dalung, Badung, 80361, Bali, Indonesia
}

Received: 09/09/2020

Accepted: 13/11/2020

Published: 20/03/2021

\begin{abstract}
The problem of breastfeeding is part of the problem of discomfort in postpartum mothers for 2 hours after giving birth. This problem often causes trauma to postpartum mothers during breastfeeding, psychological disturbances, and increases morbidity in the mother and baby due to inadequate breast milk. The practice of Oxytocin massage, Moringa leaves and Katuk leaves at the same time can improve the quantity and quality of breast milk in maternal patients with 36-40 weeks' gestation. This type of research is quantitative research. Respondents numbered 30 were selected by determining purposive sampling in each group consisting of 10 mothers. Data were analyzed using a Paired t-test and Independent sample t-test with an $\alpha$ level of 0.05 . The results showed that there was an increase in the quantity of breastfeeding. On the 3rd day, the quantity of breast milk with volume of $45 \mathrm{cc}$. In the week I with a volume of $10.50 \mathrm{cc}$, week II $86.50 \mathrm{cc}$, week III 168.50 $\mathrm{cc}$ and week IV as much as $275 \mathrm{cc}$. It shows that there are differences in quality on days 3 to week IV. The results of data analysis also showed that the 3rd day the quality of breast milk is rather yellow and rather thick, then the first week to the third week rather yellow and thin. At week IV, the quality of breast milk is white and runny. There is an increase in the quality and quantity of breast milk in all three groups.
\end{abstract}

Keywords: Breast Milk; Postpartum; Patients Health Center

\section{Introduction}

Uniqueness is something that is interesting to look at [1-9]. Women are the most unique creatures of God. Women experience menstruation, pregnancy, childbirth, and breastfeeding. The task and role of women as mothers is breastfeeding. That breast milk is more important than formula milk [10]. Both tasks and roles require different treatments for something deemed important $[11,12]$. Therefore, it is very important for a mother to take care of and take care of her breasts properly. Good and proper breast care during lactation is very necessary because it will cause the mother to feel safe and comfortable so that the mother can breastfeed her baby well [13]. Breast care must be done since pregnancy to produce quality breast milk and the sustainability of exclusive breast milk and the prevention of breastfeeding problems.

Preparation and treatment are needed in the context of interventions to improve the quality of breast milk [14]. To produce quality breast milk with smooth production requires various efforts that must be done. One of them by taking care of the breasts alternately, 2 times a day, and through the fulfillment of maternal nutrition adequacy. Nutritional requirements during pregnancy greatly affect the continuity of the mother and baby during growth. The substance component is a determinant of quality and sustainability $[15,16]$. Besides aiming to produce quality breast milk, breast care also aims to prevent breast problems during lactation.

The breastfeeding problems can affect the health and nutritional adequacy of their babies [17]. This breastfeeding problem is often caused by the wrong way of breastfeeding, mother's level of knowledge about breast care is still lacking, mothers who are less motivated or have the desire to care for breasts, mother's work and nutritional needs of mothers are not good. in pregnancy and the puerperium. Genealogy of problems for certain circles is influenced by aspects of knowledge, culture, and circumstances [18]. As breastfeeding problems are often experienced by primiparous mothers or mothers who have no experience caring for babies and herself during pregnancy and breastfeeding.

Breast care is an action carried out by the mother directly or assisted by others which are carried out starting in the third trimester of pregnancy or $>28$ weeks until the end of breastfeeding. In addition to getting maternal care, mothers should always be in a relaxed condition so that it can increase the hormone prolactin which stimulates the expenditure of breast

*Corresponding author: M'hamed Sadiq, Sultan Moulay Slimane University of Beni Mellal, Research Group in Environmental Sciences and Applied Materials (SEMA), FP Khouribga, B.P. 145, 25000 Khouribga, Morocco. Tel: +212 666248196 ; Fax: +212 523 49 0354 , Email:m.sadiq@usms.ma ; sadiqmhamed@ hotmail.com 
milk. Steps that can be taken to improve breast care are by providing information and counseling to pregnant women when doing antenatal care in preparation for breastfeeding their babies, procedures for cleaning the mother's nipples, abstinence from food during pregnancy and after delivery, procedures for pumping milk mother for mother work as preparation for breast milk for the baby when she returns to work and the proper way of breastfeeding including regulating the duration and frequency of breastfeeding through counseling, home counseling, posyandu, distributing leaflets and training health cadres to provide information and how to wean the nursing mother and teach the nursing mother how to breastfeed properly so that the mother can provide exclusive breast milk to her baby. The exclusive breastfeeding is of great benefit to the health of infants [19]. It is necessary to improve the volume of breast milk quality to be able to increase the level of infant acceptance of breastfeeding [20]. Based on these problems, the researchers are interested in conducting research on comparison of Oxytocin Massage, giving Moringa leaves and Katuk leaves on the quantity and quality of breast milk for mothers of 36-40 weeks gestational age who are preposition as patients of Abiansemal IV Health Center, Badung, Bali. In certain areas, degrees are indicative of a position [21, 22]. The health status of a country can be determined by the indicators of Maternal Mortality Rate (MMR) and Infant Mortality Rate (IMR). The Sustainable Development Goals (SDGs) target that will be achieved is to reduce child mortality by the indicator, which is to decrease the Infant Mortality Rate (IMR) to 12 / 1,000 live births in 2030 and reduce the MMR of 70 / 100,000 live births. The incidence of breast milk dams in Indonesia reaches $66 \%$. The problem of breast milk dams is only $4 \%$ for mothers who have lost their babies [23]. Based on pre-survey in the Work Area of Abiansemal IV Health Center in Badung Regency, Bali Province shows that breast problems in breastfeeding mothers $75 \%$ experience breast milk disruption on the first and second day, postpartum so that the mother's breasts are swollen. Based on the last description, then the problem can be formulated, How to Comparison of Oxytocin Massage, Giving Moringa Leaves and Katuk Leaves to the Quantity and Quality of ASI for mothers aged 36-40 weeks of pregnancy as patients of Abiansemal IV Health Center in Badung Regency, Bali Province.

\section{Materials and Methods}

Type indicates the specification of something [24, 25]. This type of research is quantitative research. This study used a quasiexperimental design with a post-test control group design. The study population was all third-trimester pregnant women who visited the working area of Puskesmas IV, Jembrana Regency, Bali Province. The sample is part of the population [26]. The research sample determined by purposive sampling. In particular, the sample in this study is part of the population that has been calculated by the researcher using the calculation of the number of research samples studied by meeting the research criteria. The sample in this study was third-trimester primiparous pregnant women who visited Abiansemal IV Community Health Center and had met the inclusion criteria. The number of samples used was 30 people. Primary data were collected using a questionnaire at the Abiansemal IV Community Health Center, Jembrana, Bali and all secondary data collected through literature studies on maternal health. All data analyzed quantitatively. Where 10 people were treated for oxytocin massage, 10 people were given Moringa leaves, and 10 people were given Katuk leaves which were processed into vegetables/side dishes.

\section{Results}

\subsection{Quantity Of Mother's Milk On Day 3}

Based on the results of the sample diversity test (normality and homogeneity of the data) that from the results indicated normal and homogeneous data distribution with p-value $\mathrm{F}(0.05)$ is 3.35 which means $3.35>0.05$ so that the data is normally distributed.

Table 1: Quantity of Mother's Milk on Day 3

\begin{tabular}{llllll}
\hline $\begin{array}{l}\text { Sources of Degrees of } \\
\text { Diversity }\end{array}$ & Freedom & $\begin{array}{l}\text { Quadrate } \\
\text { Amount }\end{array}$ & variety & F-count & F- $\alpha(0,05)$ \\
\hline Treatment & $2 .^{\mathrm{a}}$ & 3555.0 & 1777.5 & 38.014 & 3.35 \\
Galat & $27 .{ }^{\mathrm{b}}$ & 1262.0 & 46.76 & & \\
Galat & $29 .{ }^{\mathrm{b}}$ & 4817.5 & & & \\
\hline
\end{tabular}

\subsection{Quantity Of Mother's Milk On Week I}

Based on the results of the sample diversity test (normality and homogeneity of the data) that from the results indicated normal and homogeneous data distribution with p-value $\mathrm{F}(0.05)$ is 10.47 which means $10.47>0.05$ so that the data is normally distributed.

Table 2: Quantity of Mother's Milk at Week I

\begin{tabular}{lllll}
\hline $\begin{array}{l}\text { Sources of } \\
\text { Diversity }\end{array}$ & $\begin{array}{l}\text { Degrees of } \\
\text { Freedom }\end{array}$ & $\begin{array}{l}\text { Quadrate } \\
\text { Amount }\end{array}$ & variety & F-count F- $\alpha(0,05)$ \\
\hline Treatmentt & $2 .^{\mathrm{a}}$ & 7145 & 3572,5 & \\
Galat & $27 .^{\mathrm{b}}$ & 3522,5 & 130,463 & $27,38310.47$ \\
Galat & $29 .^{\mathrm{b}}$ & 10667,5 & & \\
\hline
\end{tabular}

\subsection{Quantity Of Mother's Milk On Week II}

Based on the results of the sample diversity test (normality and homogeneity of data) that the results can be shown normal and homogeneous data distribution with p-value $F(0.05)$ is 3.35 which means $3.35>0.05$ so that the data is normally distributed.

Table 3: Quantity of Mother's Milk at Week II

\begin{tabular}{llllll}
$\begin{array}{l}\text { Sources of } \\
\text { Diversity }\end{array}$ & $\begin{array}{l}\text { Degrees of } \\
\text { Freedom }\end{array}$ & $\begin{array}{l}\text { Quadrate } \\
\text { Amount }\end{array}$ & variety & F-count & F- $\alpha(0,05)$ \\
\hline Treatment & $2 \cdot^{\mathrm{a}}$ & 1985 & 992,5 & 14,929 & 3,35 \\
Galat & $27 .^{\mathrm{b}}$ & 1795 & 66,481 & & \\
Galat & $29 .^{\mathrm{b}}$ & 3780 & & & \\
\hline
\end{tabular}

\subsection{Quantity Of Mother's Milk On Week III}

Based on the results of the sample diversity test (normality and homogeneity of the data) that from the results indicated normal and homogeneous data distribution with p-value $\mathrm{F}(0.05)$ is 13.26 which means $13.26>0.05$ so that the data is normally distributed.

\subsection{Quantity Of Mother's Milk On Week IV}

Based on the results of the sample diversity test (normality and homogeneity of data) that the results showed normal and homogeneous data distribution with p-value $\mathrm{F}(0.05)$ is 3.984 which means $3.984>0.05$ so that the data is normally distributed.

Table 4: Quantity of Mother's Milk at Week III 


\begin{tabular}{llllll}
\hline $\begin{array}{l}\text { Sources of } \\
\text { Diversity }\end{array}$ & $\begin{array}{l}\text { Degrees of } \\
\text { Freedom }\end{array}$ & $\begin{array}{l}\text { Quadrate } \\
\text { Amount }\end{array}$ & variety & F-count F- $\alpha$ \\
& & & $(0,05)$ \\
\hline Treatment & $2 .^{\mathrm{a}}$ & 20171,67 & 10085,83 & 48,18 & 13,26 \\
Galat & $27 .^{\mathrm{b}}$ & 5652,5 & 209,35 & & \\
Total & $29 .^{\mathrm{b}}$ & 25824,17 & & & \\
\hline
\end{tabular}

Table 5: Quantity of Mother's Milk at Week IV

\begin{tabular}{llllll}
\hline Sources of & \multicolumn{2}{l}{ Degrees of Quadrate } & Variety & F-count F- $\alpha$ \\
Diversity & Freedom & Amount & & $(0,05)$ \\
\hline Treatment & $2 .^{\mathrm{a}}$ & 67706,667 & 33853,333 & 17,926 & 39,84 \\
Galat & $27 .{ }^{\mathrm{b}}$ & 50990 & 1888,519 & & \\
Galat & $29 .^{\mathrm{b}}$ & 118696,667 & & & \\
\hline
\end{tabular}

\section{Discussion}

A supplementary nutrition program specifically for women and infants could harm breast milk transmission [27]. On the contrary, the results of this study prove that by giving Oxytocin massage therapy, Moringa leaves and Katuk leaves can increase the volume and appearance of breast milk. The need for health assistance in the process of breastfeeding to reduce the problem of social and ethnic disparity [28]. The results of the research in three research groups involving 30 samples by the research hypothesis and research objectives can be discussed narratively based on the results of the research table as follows.

1.Achieving improvements in maternal breast milk can produce parental satisfaction as well as trust and social support for the source of the health therapy process [29]. Knowing the quality and quantity of breast milk during lactation after being given oxytocin massage as therapy to mothers of 36-40 weeks' gestation. Based on the results of data analysis that the quantity of breast milk is measured on the 3rd day, week I, II, III and IV which have been tested for normality of data so that the data are normally distributed on the 3rd day the quantity of breast milk with an average volume $20 \mathrm{cc}$, in week I with a volume of $86 \mathrm{cc}$, week II $86.50 \mathrm{cc}$, week III $113 \mathrm{cc}$ and week IV as much as 225 cc which means an increase in the quantity of breast milk every week. If using domperidone, an increase in the volume of breast milk could increase by $88.3 \mathrm{ml} /$ day (95\% CL 56.8-119.8) [30]. 2.Knowing the quality and quantity of breast milk during lactation after given Moringa leaves on mothers 36-40 weeks' gestation. Based on the results of data analysis that the quantity of breast milk is measured on the 3rd day, week I, II, III and IV which have been tested for normality of data so that the data are normally distributed on the 3rd day the quantity of breast milk with an average volume $45 \mathrm{cc}$, in week I with a volume of 10.50 cc, week II $86.50 \mathrm{cc}$, week III $168.50 \mathrm{cc}$ and week IV as much as $275 \mathrm{cc}$ which means an increase in the quantity of breast milk every week. Based on the quality of breast milk that there are differences in quality on day 3 to week IV where in the results of data analysis that day 3 the quality of breast milk is rather yellow, and rather thick with an average of $3.80 \mathrm{cc}$ and then week I to III an average of $4.9 \mathrm{cc}$ which means it is rather yellow and runny. At week IV, the quality of milk is white and runny with an average of $5.0 \mathrm{cc}$.

3.Knowing the production of breast milk during lactation after given Katuk leaves to mothers aged 36-40 weeks gestation. Based on the results of data analysis that the quantity of breast milk is measured on the 3rd day, week I, II, III and IV which have been tested for normality of data so that the data are normally distributed on the 3rd day the quantity of breast milk with an average volume an average of $26 \mathrm{cc}$, in week I with a volume of $86 \mathrm{cc}$, week II $86 \mathrm{cc}$, week III $114 \mathrm{cc}$ and week IV as much as $159 \mathrm{cc}$ which means an increase in the quantity of breast milk every week. The volume of breast milk quality can increase significantly on the 7th day after consultation during the therapy process [31]. Based on the quality of breast milk that there is a difference in quality on day 3 to week-IV where the results of data analysis show that when entering day 3 , the quality of breast milk is rather yellow, and rather thick with an average of $2.80 \mathrm{cc}$ then weeks I through IV an average of $3.8 \mathrm{cc}$ which means that the breast milk is rather yellow and runny.

The results of the research confirmed that Moringa Leaves, Katuk Leaves, and Oxytocin Massage therapies affected the changes in the quantity of breast milk and changes in the quality of breast milk for Abiansemal IV Health Center patients in Badung Regency, Bali Province. Changes in the volume of breast milk quality occurred significantly since pregnant women as patients undergo therapy using Katuk Leaves. This is in line with the allegations in this research, the impact of giving each Moringa Leaves therapy, Katuk Leaves, and Oxytocin Massage is able to increase the quantity and quality of breast milk of Abiansemal IV Health Center patients in Badung Regency, Bali Province.

\section{Conclusion}

There was an increase in the quantity of breast milk in the group of women who received oxytocin massage on the 3rd day the quantity of breast milk with an average volume of $20 \mathrm{cc}$, on week I with a volume of $86 \mathrm{cc}$, week II had a volume of 86.50 cc, week III had a volume $113 \mathrm{cc}$ and 225 weeks IV, which can be explained that there has been an increase in the quantity of breast milk every week and the quality of breast milk that occurs does not show an increase in the quality of breast milk. An increase in the quantity of breast milk in mothers Katuk leaf group entered the 3rd day, week I, II, III and IV that have been tested for normality of data so that the data are normally distributed. On the 3rd day the quantity of breast milk with an average volume of $45 \mathrm{cc}$, in the first week with a volume of 10.50 $\mathrm{cc}$, the second week had a volume of $86.50 \mathrm{cc}$, week III had a volume of $168.50 \mathrm{cc}$ and the fourth week was $275 \mathrm{cc}$ means there has been an increase in the quantity of Mother's Milk every week. In the quality of breast milk that there is a difference in quality on day 3 to week IV where in the results of data analysis that the 3rd day the quality of breast milk is slightly yellow in color and the quality is rather thick with an average of $3.80 \mathrm{cc}$ then the week to I to III averaged a volume of $4.9 \mathrm{cc}$ which means that the breast milk is rather yellow and runny and at week IV, the quality of breast milk is white and runny with an average of 5.0. Quantity of breastfeeding is measured on the 3rd day, week I, II, III and IV which have been tested for normality of the data, so the data is normally distributed. On the 3rd day the quantity of breast milk has an average volume of $26 \mathrm{cc}$, in week I with a volume of $86 \mathrm{cc}$, week II has a volume of $86 \mathrm{cc}$, week III has a volume of $114 \mathrm{cc}$ and week IV has $159 \mathrm{cc}$ which means that there has been an increase in water quantity mother's milk every week. In relation to the quality of breast milk, it can be stressed that there are differences in quality on days 3 to week IV where the results of data analysis show that breast milk quality is rather yellow and rather thick with an average volume of $2.80 \mathrm{cc}$ then weeks I through IV an average of $3.8 \mathrm{cc}$ which means that the breast milk is rather yellow and runny. It can be seen that there is a significant relationship between giving Katuk leaves to the quantity and quality of breast milk. The quantity and quality of 
breast milk also seems to increase after being given Moringa leaves and Oxytocin massage.

\section{Aknowledgment}

Thanks to the Puskesmas IV Jembarana Bali and the patients involved in this research.

\section{Ethical issue}

Authors adhere to the publication requirements that the submitted work is original and has not been published elsewhere in any language.

\section{Competing interests}

The author states that there is no conflict of interest in this scientific work.

\section{Authors' contribution}

The authors of this research have a complete contribution to scriptwriting.

\section{References}

[1] Pradana, Gede Yoga Kharisma. Deconstruction Powers of Relations Behind The Shadow Puppet Performance For Tourism in Ubud Village, Bali. Paper presented at the Building Collaboration and Networking in Globalized World, 2017, 1: 115-124. Denpasar: UNUD Press.

[2] Pradana, Gede Yoga Kharisma. Implications of Commodified Parwa Shadow Puppet Performance For Tourism in Ubud, Bali. Journal of Business on Hospitality and Tourism, 2018; 4(1): 70-79. doi: http://dx.doi.org/10.22334/jbhost.v4i1.103.g111.

[3] Pradana, Gede Yoga Kharisma, I Wayan Pantiyasa. Makotek As Tourist Attraction in Munggu Village. Paper presented at the International Conference on Tourism, Gastronomy and Tourist Destination (ICTGTD), 2018,2: 10-18. Jakarta : Atlantis Press.

[4] Pradana, Gede Yoga Kharisma Pradana. Innovation in Cenk Blonk Performance : A Strategy of Empowering Local Language Through Balinese Shadow Puppet. Paper Presented at the International Conference on Local Language, 2018a, 1:173-182. Denpasar : UNUD Press.

[5] Pradana, Gede Yoga Kharisma Pradana. (2018b). The Meaning of Makotek Tradition at The Munggu Village on The Global Era. Paper presented at the International Bali Hinduism, Tradition and Intereligious Studies, 2018b,1:122-128. Denpasar : UNUD Press.

[6] Rai, I Wayan, Made Indra Sadguna, I Gde Agus Jaya Sadguna, Gede Yoga Kharisma Pradana. Tifa From The Land of Papua : Text and Context. Asia Life Sciences, 2019; 28(2): 335-354.

[7] Ruastiti, Ni Made, Gede Yoga Kharisma Pradana, I Gusti Ketut Purnaya, Komang Shanty Muni Parwati. The Royal Dinner Party Puri Anyar Kerambitan Tabanan : A Sustainable Cultural Tourism Attraction Based on Local Community. Paper Presented at the 1st International Conference on Social Science, Education and Humanities, 2018, 1:1448-1459. Nusa Dua: Atlantis Press.

[8] Pradana, Gede Yoga Kharisma, Komang Trisna Pratiwi Arcana. Balinese Traditional Homestay in a Sustainable Tourism Entering Millennial Era. Journal of Xi'an University of Architecture \& Technology, 2020; 12(3): 4208-4217. doi: https://doi.org/10.37896/JXAT12.03/367.

[9] Ruastiti, Ni Made, Gede Yoga Kharisma Pradana. The Ideology Behind Sesandaran Dance Show in Bali. Journal of Sociology and Social Anthropology, 2020; 11(2): 78-85. doi: 10.31901/24566764.2020/11.1-2.348.

[10]Scott, Allison, Marilou Shreve, Britni Ayers, Pearl Ana McElfish. Breast-Feeding Perceptions, Beliefs and Experiences of Marshallese
Migrants : An Exploratory Study. Public Health Nutrition, 2016; 19(16): 3007-3016.

[11] Arniati, Ida Ayu Komang, Gede Marhaendra Wija Atmaja, Gede Yoga Kharisma Pradana. Moral and Religious Values in The Geguritan Dharma Prawerti Song in Bali. International Journal of Innovation, Creativity and Change, 2020; 12(1): 432-446.

[12]Dharmika, Ida Bagus, Gede Yoga Kharisma Pradana, Ni Made Ruastiti. Forest Conservation With The Basis Of Customary Village and Religion Rules in Bali. International Journal of Advanced Science and Technology, 2020; 29(8): 571-579.

[13]Prawirohardjo, Sarwono. Buku Panduan Praktis Pelayanan Kontrasepsi Edisi 3. Jakarta : PT. Bina Pustaka Sarwono Prawirohardjo. Jakarta, 2012: 300 pages.

[14]Leeman, Kristen T., Kimberly Brabas, Julia Strauss, Shannon Adams, Karen Sussman-Karten, Alyssa Kelly, Margaret G. K. Parker, Anne Hansen. Improving Access to Lactation Consultation and Early Breast Milk Use in an Outborn NICU. Pediatric Quality and Safety, 2019; 4(1): 2-7.

[15]Pradana, Gede Yoga Kharisma, I Nyoman Suarka, Anak Agung Bagus Wirawan, I Nyoman Dhana. Religious Ideology of The Tradition of The Makotek in The Era of Globalization. Electronic Journal of Cultural Studies, 2016; 9(1): 6-10.

[16]Pradana, Gede Yoga Kharisma. Filsafat Ilmu Pariwisata. STPBI Denpasar, 2017a; 117 pages.

[17] Grzeskowiak, L., L. Smithers, L. Amir, R. Grivella. Domperidone for Increasing Breast Milk Volume in Mothers Expressing Breast Milk for Their Preterm Infants : a Systematic Review and MetaAnalysis. An International Journal of Obsterics and Gynaecology, 2018;125(1):1371-1378. doi : 10.1111/1471-0528.15177.

[18]Pradana, Gede Yoga Kharisma. Diskursus Fenomena Hamil di Luar Nikah dalam Pertunjukan Wayang Joblar. Online Journal of Cultural Studies, 2012; 1(2): 11-27.

[19] Kalluri, Nikita S., Burnham, Laura A, Lopera, Adriana M., Stickney, Donna M., Combs, Ginny L, Levesque, Bernadette M, Philipp, Barbara L, Parker, Margaret G. A Quality Improvement Project to Increase Mother's Milk Use in an Inner-City NICU. Pediatric Quality and Safety, 2019;4(5):1-8. doi : $10.1097 / \mathrm{pq} 9.0000000000000204$.

[20]Fugate, Karen, Ivonne Hernandez, Terri Ashmeade, Branko Miladinovic, Diane L. Spatz. Improving Human Milk and Breastfeeding Practice in the NICU. Journal of Obstetric, Gynecologic \& Neonatal Nursing, 2015;44(3): 426-438. doi: https://doi.org/10.111/1552-6909.12563.

[21] Atmaja, Gede Marhaendra Wija, Ida Ayu Komang Arniati, Gede Yoga Kharisma Pradana. Implications of The Enacment of Law Number 6 of 2014 on The Position of Villages in Bali, Indonesia. Asia Life Sciences, 2019; 28(2): 295-310.

[22] Tejayadi, Putu Windhu, I Nengah Laba, Gede Yoga Kharisma Pradana. The Effect of Organizational Culture on Employee Satisfaction in Mercure Resort Sanur Bali Hotel. The International Journal of Green Tourism Research and Applications, 2019;1(1): 63-72.

[23]Depkes RI. Profil Kesehatan Tahun 2016. Jakarta : Dinas Kesehatan Kota Surabaya. Jakarta, 2016; 76 pages.

[24]Pradana, Gede Yoga Kharisma, Komang Shanty Muni Parwati. Local-Wisdom-Based Spa Tourism in Ubud Village of Bali, Indonesia. Russian Journal of Agricultural and Socio-Economic Sciences, 2017; 8(68): 188-196. doi: 10.18551/rjoas.2017-08.22.

[25] Pradana, Gede Yoga Kharisma. Sosiologi Pariwisata. STPBI Press. Denpasar, 2019; 88 pages.

[26] Sugiyono. Metodologi Penelitian Kuantitatif Kualitatif dan R \&D. Alfabeta. Bandung, 2009; 464 pages.

[27]Scott, Allison, Marilou Shreve, Britni Ayers, Pearl Ana McElfish. Breast-Feeding Perceptions, Beliefs and Experiences of Marshallese Migrants : An Exploratory Study. Public Health Nutrition, 2016;19(16): 3007-3016.

[28] Kalluri, Nikita S., Burnham, Laura A, Lopera, Adriana M., Stickney, Donna M., Combs, Ginny L, Levesque, Bernadette M, Philipp, Barbara L, Parker, Margaret G. A Quality Improvement Project to 
Increase Mother's Milk Use in an Inner-City NICU. Pediatric Quality and Safety, 2019; 4(5): 1-8. doi : $10.1097 / \mathrm{pq} 9.0000000000000204$.

[29]Fugate, Karen, Ivonne Hernandez, Terri Ashmeade, Branko Miladinovic, Diane L. Spatz. Improving Human Milk and Breastfeeding Practice in the NICU. Journal of Obstetric, Gynecologic \& Neonatal Nursing, 2015;44(3): 426-438. doi: https://doi.org/10.111/1552-6909.12563.

[30] Grzeskowiak, LE, LG Smithers, LH Amir, RM Grivella. Domperidone for Increasing Breast Milk Volume in Mothers Expressing Breast Milk for Their Preterm Infants : a Systematic Review and Meta-Analysis. An International Journal of Obsterics and Gynaecology, 2018;125(1):1371-1378. doi : 10.1111/14710528.15177.

[31]Leeman, Kristen T., Kimberly Brabas, Julia Strauss, Shannon Adams, Karen Sussman-Karten, Alyssa Kelly, Margaret G. K. Parker, Anne Hansen. Improving Access to Lactation Consultation and Early Breast Milk Use in an Outborn NICU. Pediatric Quality and Safety, 2019; 4(1): pp. 2-7. 